\title{
Dyskursywne uprawomocnienie refleksji teoretycznej w naukach o polityce
}

\section{Discursive Validation of Theoretical Reflection in Political Sciences}

\begin{abstract}
The article addresses the topic of scientific validation of theoretical reflection in the context of academic discourse. The primary thesis states that the status of a stance, school or a theoretical tradition is, on the one hand, determined by factual arguments relying on rational justification and explanatory pragmatism, and on the other hand, by numerous irrational factors that determine contemporary discourse in scientific community. The author focuses on both cultural, systemic and institutional determinants of discourse.
\end{abstract}

Keywords: theory of politics, political theory, academic discourse, scientific validation of knowledge, theoretical reflection

Inicjatywa powołania nowego czasopisma poświęconego teoretycznej refleksji nad polityką w czasach, gdy badania teoriopolityczne wytraciły swój niedawny impet, a dyskurs politologiczny wydaje się zdominowany przez przedstawicieli badań empirycznych oraz zwolenników politologii stosowanej, jest niewątpliwie decyzją odważną, a także inspirującą. Skłania bowiem do zastanowienia nad czynnikami decydującymi, nie tyle o modzie i popularności, co po prostu o obecności i skali zastosowania określonego typu badań, form refleksji, podejścia teoretycznego czy choćby podejmowanej tematyki badawczej.

Współcześnie zachodzące zmiany w dyskursie akademickim w znaczącym stopniu dotyczą funkcjonalnych relacji między wiedzą naukową a praktyką społeczną. Charakterystyczny w tym względzie jest trend rozwoju rozmaitych centrów transferu wiedzy i technologii, ukierunkowanych na dynamiczną komercjalizację wysiłków badawczych. Podobne temu trendy ilustrują zasadniczy zwrot $\mathrm{w}$ przesunięciu akcentu $\mathrm{z}$ idei wiedzy pewnej na wiedzę użyteczną. Jednocześnie $\mathrm{w}$ sposób zdecydowany dowartościowują badania stosowane, niekie- 
dy sporym kosztem badań podstawowych. Dzięki temu środowisko akademickie omija kłopotliwe spory co do formułowanych apriorycznie, a empirycznie nierozstrzygalnych założeń, wyznaczając w zamian bardzo pragmatyczne kryteria uprawomocnienia i ewaluacji wiedzy. Fundamentalnym kryterium uprawomocnienia w tej pragmatycznej perspektywie jest przede wszystkim wkład nauki w polepszanie warunków i zmianę jakościową życia społecznego.

Refleksja teoretyczna i charakterystyczne dla niej badania podstawowe w warunkach logicznej nierozstrzygalności ontologicznych i epistemologicznych antynomii nadal nie mogą wyjść z impasu, brak bowiem arbitralnego orzeczenia rozwiązującego problem prawomocności oglądu proponowanego przez poszczególne stanowiska badawcze. Stąd przekonanie, że w sytuacji braku autonomicznego i obiektywnego arbitrażu uprawomocnienie dociekań teoretycznych może być następstwem uznania racjonalnej argumentacji, uzasadniającej poprawność i adekwatność myślenia w opinii badaczy reprezentujących inną perspektywę poznawczą. Istotą uprawomocnienia staje się więc proces negocjowania i ustalania znaczeń oraz wartości bądź kryteriów, których wynikiem jest intersubiektywna konwencja oparta na akceptacji uzasadnień niepoddających się krytyce konkurencyjnych stanowisk poznawczych. W tych okolicznościach politologia, podobnie jak cała humanistyka, jest rodzajem komunikacji, a samo badanie polityki już u swej genezy jest formą dialogu badacza $\mathrm{z}$ jego środowiskiem zawodowym (Strydom, 2000, s. 9-14).

$\mathrm{Z}$ tych względów nie tyle formalno-logiczne kryteria, co dyskurs akademicki staje się istotną przestrzenią uprawomocnienia wysiłków badawczych teoretyków. Nie oznacza to jednak, iż mniej sformalizowana forma dyskursywnego uzasadnienia nie ma charakteru racjonalnego. Jak trafnie zauważa John S. Nelson, niezależnie od różnic w podejściach teoretycznych bądź stosowanych metod badawczych refleksja spekulatywna, podobnie jak i matematyczne modele, logiczne macierze czy ekonometryczne tabele, jako ostateczny argument uprawomocniający swoje wywody odnosi się do racjonalnej argumentacji. Tylko taki charakter uzasadnienia ma bowiem szansę zostać uznany przez przedstawicieli innych podejść (Nelson, 1998, s. 5-6) ${ }^{1}$.

Optyka ta obliguje do zwrócenia uwagi na dyskurs jako jeden z głównych czynników wyznaczających formułę uprawomocnienia dla teoretycznych rozstrzygnięć i metodologicznych ustaleń, a w konsekwencji także dla statusu teorii polityki w ramach nauk o polityce. Przy czym charakterystyka dyskursu pozwala dostrzec, iż uprawomocnienie poszczególnych stanowisk teoretycznych nie jest dokonywa-

J.S. Nelson podkreśla zarazem, iż tę zasadniczą właściwość procesów poznania zupełnie pominęła tradycja behawioralna, a obecnie kontynuuje ten błąd teoria racjonalnego wyboru (Nelson, 1998 , s. 100-110). 
ne tylko za pomocą formalnych czy też ontologicznie „obiektywnych” kryteriów analitycznych, lecz intersubiektywnie wyznaczane $\mathrm{w}$ ramach dyskursywnie ustalanych konwencji. Określenia te nawiązują do dychotomicznego podziału obiektywności przytaczanego przez Williama McKinleya. Odróżnia on absolutną bądź ontologiczną obiektywność, która obrazuje ostateczną (ultimate) strukturę rzeczywistości, oraz obiektywność pozapoglądową (aperspectival), która jest rezultatem eliminacji partykularnych (indywidualnych bądź niekiedy grupowych) form recepcji. W metodologii badań wyodrębnia się jeszcze inne jej formy np. obiektywność dyscyplinarną, dialektyczną czy proceduralną (McKinley, 2003, s. 143).

W tym kontekście dyskursywność można rozumieć w sensie organizowanych $\mathrm{w}$ sferze publicznej debat czy wypowiedzi związanych $\mathrm{z}$ naukową sferą życia społecznego, których zasadniczą cechą jest znaczący wpływ na poglądy, postawy i działania badaczy. Przy czym dyskursywność procesów uprawomocnienia wiedzy wyraża się także w mechanizmach wypracowywania właściwych sposobów prowadzenia sporów badawczych, użycia języka czy naukowych pojęć. W ramach prowadzonych w ten sposób debat czy polemik wypracowywane są stanowiska wyznaczające status poszczególnych twierdzeń czy pozycji w strukturze systemu wiedzy naukowej, weryfikację możliwości ich zastosowań badawczych, w tym warunków i granic ich eksploracji, a także charakteryzowane są zależności między danymi podejściami. Taka interpretacja dyskursu naukowego uwzględnia ujmowanie go jako głównej przestrzeni, w której dokonywana jest dystrybucja wpływu na proces kształtowania orientacji teoretycznych i sposobów ich uprawomocnienia (Strydom, 2000, s. 49).

Odwołanie się do dyskursu w charakterystyce wiedzy naukowej jest ścisłą konsekwencją ujmowania jej jako jednej z form procesów społecznych. $\mathrm{W}$ tej perspektywie dyskursywny charakter wiedzy naukowej implikuje uwzględnianie szerokiego katalogu uwarunkowań społecznych, od kulturowych aspektów poznania, poprzez jej instytucjonalne formy, aż do historycznych okoliczności i roli organizacyjnych zasobów². Mają one istotny wpływ na strukturyzację badań i relację między tradycjami teoretycznymi, które wyznaczane są przez dominację $\mathrm{w}$ realizowanych programach badawczych. $\mathrm{Z}$ tego punktu widzenia to praktyka zastosowania danego podejścia badawczego wynikająca $z$ oceny jego użyteczności eksplanacyjnej, a nie zgodność z formalistyczną procedurą wyjaśniania, realnie decyduje o ważności formułowanych interpretacji i stopniu jego instytucjonalizacji. Symptomatyczne w tym względzie jest stanowisko Jonathana H. Turnera, który wychodząc z perspektywy charakterystycznej dla empirycznego modelu nauki, dostrzega jednak konieczność uwzględniania także tych po-

Szerzej o współczesnych ekonomiczno-instytucjonalnych uwarunkowaniach dyskursu w naukach społecznych zob.: Novotny, 1991, s. 23-40; Dant, 1991, s. 3-4. 
dejść teoretycznych, które mimo iż według kryteriów autora są „antynaukowe”, oferują jednak użyteczny eksplanacyjnie wgląd w badaną rzeczywistość.

Oceniając teorie, trzeba zadawać sobie zawsze dwa podstawowe pytania. Pierwsze, czy teoria jest antynaukowa, a jeśli tak, to czy mimo to jest jakoś użyteczna? Może bowiem być tak, że chociaż sami teoretycy są antynaukowi, to jednak z ich prac można wydobyć użyteczne elementy naukowe. Kwestią kluczową nie jest więc antynaukowa retoryka. Lecz zdolność dostrzeżenia, czy teorie zawierają jakąś siłę eksplanacyjną i czy mogą ją przekształcić w bardziej naukowe. Jeśli można to należy je rozwijać, jeśli nie, powinny zostać zarzucone (Turner, 2004, s. XXIII).

Tak zakreślona rola dyskursu w procesie oceny potencjału eksplanacyjnego i w konsekwencji pragmatycznego uprawomocnienia badań wydaje się fundamentalna. W ten sposób to głównie w ramach dyskursywnej konfrontacji stanowisk, ustalania ważności twierdzeń i zakresu ich zastosowania w programach badawczych oraz możliwości wyjaśniania poszczególne tradycje uzyskują swoją naukową doniosłość, rangę oraz przynależny im status eksplanacyjny. Prawidłowości te akcentuje m.in. pogląd George’a Ritzera, który uzależnia uzyskanie statusu klasyki socjologicznej od trzech cech, jakimi powinna się ona charakteryzować, takich jak szeroki zasięg implikacji, koncentracja na centralnych zagadnieniach czy problemach społecznych oraz wytrzymałość na krytykę w dłuższym czasie (Ritzer, Goodman, 2004, s. 4).

W tej perspektywie naukowa wiedza o polityce jest więc formą dyskursu, którego uczestnikami są uprawomocnione do wypowiedzi orientacje badawcze, a jego treść i forma są uwarunkowane strukturą i zakresem realizowanych przez nie programów badawczych. Zawarta $w$ tej definicji teza zaprzecza empirycznemu modelowi nauki o polityce, który odwołując się do stanowiska naturalistycznego, utrzymuje, iż wiedza powinna być bezpośrednim odzwierciedleniem praktyki politycznej i to wierność obrazu decyduje o ważności formułowanych orzeczeń 3 . Pogląd ten zakłada jednak, iż w politologii, podobnie jak w naukach naturalnych, empiryczna natura badanego obiektu nie podlega kwestionowaniu. $\mathrm{Z}$ tego punktu widzenia, tak jak w podejściu badawczym biologa czy fizyka, najważniejszą z metodologicznego punktu widzenia kwestią jest zgodność postępowania $z$ obowiązującą procedurą dowodzenia i poprawnością weryfikacji uzyskanych wyników. Jednak w przypadku badacza społecznego problemem analitycznie wcześniejszym i z tego względu często ważniejszym jest określenie

$\mathrm{W}$ tradycyjnym modelu nauki bezpośredniej konfrontacji badacza $\mathrm{z}$ badaną rzeczywistością służyć ma zasada empirycznej weryfikacji zawarta w procedurze, opartej na trzech zasadniczych elementach: teorii, operacjonalizacji i obserwacji (Babbie, 2004, s. 67-70). 
natury obszaru badawczego, uzasadnienie przyjętego stanowiska poznawczego oraz potwierdzenie zasadności zastosowanego instrumentarium metodologicznego (Krauz-Mozer, 2007, s. 20-26).

Ten szeroko uzasadniany w podejściu interpretatywnym pogląd, opiera się na oczywistej konstatacji, iż żadna jednostka nie może objąć swoją indywidualną perspektywą poznawczą sposobu recepcji świata innego człowieka, jego emocjonalnych motywacji czy osobowościowych i aksjologicznych imperatywów działania. Tym trudniej jest także uchwycić złożone determinanty i prawidłowości działań zbiorowych bądź grupowych, które nie muszą być prostą sumą działania indywidualnego. $\mathrm{W}$ tych okolicznościach żaden badacz nie może być pewny, że odtworzony obraz jest bezstronny, obiektywny i adekwatny do rzeczywistego. $Z$ tego punktu widzenia dyskurs okazuje się niezbędnym elementem procesu „obiektywizacji” poznawczej i tworzy punkt odniesienia dla interpretacyjnej perspektywy każdego badacza. Ta prawidłowość tworzy też podstawę do legitymizacji kolektywistycznej perspektywy etyki poznania naukowego (Thompson, 1998, s. 39-42).

W konsekwencji o ile głównym zadaniem badawczym przedstawicieli nauk naturalnych jest odkrywanie nowych faktów czy zjawisk przyrodniczych, humanistom wiele czasu zajmuje problem konceptualizacji własnego obszaru badań. W tej perspektywie politolog, podobnie jak przedstawiciel innych dyscyplin społecznych, nie staje w bezpośredniej konfrontacji z obiektem swojego badania, lecz z określoną jego interpretacją, będącą jedną z wielu możliwych form postrzegania. Skutkiem tego także wiedza o polityce nie jest prostym odzwierciedleniem samej polityki, ale powstaje jako rezultat dialogu i ścierania się argumentów formułowanych i konstruowanych przez poszczególne tradycje teoretyczne ${ }^{4}$.

Występujące $\mathrm{w}$ literaturze pojęcia dyskursu naukowego czy akademickiego bądź ważnych debat badaczy społecznych (important social scientific debates) mają interdyscyplinarne odniesienie ${ }^{5}$. W perspektywie politologicznej najbliższe mu określenie dotyczyłoby „dyskursu badaczy polityki” lub „dyskursu politologicznego", który w najogólniejszym znaczeniu można zdefiniować jako wymianę poglądów i konfrontację idei kształtujących wiedzę o polityce oraz instytucjonalne i organizacyjne formy jej komunikowania przyjęte $w$ danym czasie. Jest on więc interaktywną formą wymiany informacji, z racji której dokonuje się rozbudowy i weryfikacji argumentów uzasadniających i obiektywizujących okreś-

\footnotetext{
Szerzej argumenty przemawiające za konstruktywistycznym charakterem dyskursywnie wyznaczanego obszaru badań w naukach społecznych zob. McKinley, 2003, s. 143-148.

Według Stanisława Gajdy termin „dyskurs naukowy” należy do treściowo niedookreślonych i nieostrych. Wiąże się on „z całą rodziną znaczeń starszych i nowszych, kształtowanych na różnych obszarach badań i w różnych celach". W obrębie dyskursu naukowego tradycyjnie wyróżnia się: dyskurs nauk ścisłych i dyskurs nauk humanistycznych, w ramach których można wyodrębnić jeszcze dyskursy poszczególnych dyscyplin. Szerzej zob. Gajda, 1999, s. 9-17.
} 
lone stanowiska badawcze. Taka forma interpretacji dyskursu politologicznego akcentuje również funkcjonalno-treściowe i historyczno-socjologiczne aspekty dyskursu. Według charakterystyki Stanisława Kamińskiego kontekst historyczno-socjologiczny obejmuje instytucje, działalność uczonych i ich wytwory, a także narzędzia i środki pozwalające na prowadzenie tej działalności. Z kolei kontekst funkcjonalno-treściowy nastawiony jest na poznanie i jego formy, które ukierunkowane są na formułowanie wiedzy obiektywnej względem „zewnętrznej rzeczywistości” (Kamiński, 1981, s. 19).

Uwzględniając oba te konteksty, można dostrzec, iż dyskurs politologiczny posiada dwoistą, odmienną naturę. W funkcjonalno-treściowym kontekście, gdzie dyskurs tworzy podstawę do strukturyzacji badań, na pierwszy plan wysuwają się debata, dialog i polemika. Taki charakter dyskursu politologicznego wynika przede wszystkim ze specyfiki form procesów komunikacji wewnątrz środowiska naukowego opartych na racjonalnym przekonywaniu. W tym kontekście ma on wiele wspólnego z habermasowską naturą dyskursu komunikacyjnego. Rywalizacja o status danej tradycji i stopień przypisywanego jej autorytetu nie tyle opiera się tu na instytucjonalnym uprawomocnieniu czy organizacyjnych zasobach, ile łączy się z siłą argumentów składających się na uzasadnienie stanowiska badawczego. Cechą dyskursu w tym wymiarze jest więc dążenie do porozumienia i akceptacji formułowanych przez badaczy sądów w ramach racjonalnych reguł przekonywania (Crossley, 2005, s. 60-63). Wynika to z faktu, iż komunikacja między badaczami oparta jest na zamiarach uprawomocnienia swoich wysiłków, które w racjonalnym dyskursie może nastąpić tylko wskutek środowiskowego uznania użyteczności eksplanacyjnej. Trudno przy tym wyobrazić sobie taką ocenę bez przyjęcia określonego konsensu co do podstawowych reguł wyznaczających cechy prawomocnego poznania. Tylko za przyczyną wypracowanego w środowiskach akademickich porozumienia możliwe są komunikacja, konstruktywna krytyka i naukowy postęp. W konsekwencji, jak zauważa Barbara Krauz-Mozer, ta cecha dyskursu „,jest zasadą działalności naukowej jednoczącą wysiłki badaczy" (Krauz-Mozer, 2007, s. 25).

Wydaje się, iż w tej postaci dyskursu politologicznego najważniejszą rolę odgrywają dwie, nieco alternatywne jego odmiany. $Z$ jednej strony decydujący wpływ na stanowiska badaczy polityki mają argumenty formułowane w trakcie polemiki akademickiej, które wyrażane są głównie w formie publikowanych monografii i opracowań, uznanych przez środowisko jako autorytatywne i opiniotwórcze ${ }^{6}$. Z drugiej strony stanowiska, a także procedury badawcze są kształtowane $\mathrm{w}$ trakcie debat prowadzonych na prestiżowych konferencjach i sym-

Przykładem publikacji opartej na konwencji panelowej polemiki, w której poglądy danego badacza są opatrzone komentarzem krytyków, jest opracowanie zbiorowe Mansfield, Sisson, 2003. 
pozjach naukowych, które umożliwiają bezpośrednią artykulację poglądów reprezentowanych przez wybitne postaci świata nauki. W obu tych formach dyskursu kształtowane są wzorce uprawomocnionych podejść badawczych i standardy badań politologicznych. Następująca tu konfrontacja stanowisk, ścieranie argumentów i wypracowywane konsensy wyznaczają również zakres uprawomocnienia poszczególnych tradycji badawczych oraz ich status w hierarchii potencjału eksplanacyjnego. O racjonalności takiej formuły dyskursu akademickiego przekonuje m.in. argumentacja Jürgena Habermasa zawarta w jego koncepcji komunikacji. Zakłada ona m.in., iż niezależnie od rzeczywistych motywacji badaczy argumenty formułowane $\mathrm{w}$ debacie mają charakter przekonywania racjonalnego opartego na szerszej akceptacji reguł rozstrzygania racji (Habermas, 2005). Istotę racjonalności tak rozumianego dyskursu oddaje trafnie Florian Znaniecki, pisząc: „badacz nie może odwołać się ani do autorytetu grupy, ani do osobistego interesu”, lecz musi „przekonać scholarzy, do jego szkoły nie należących, że tylko jej uroszczenia są obiektywne, uroszczenia zaś każdej innej szkoły, która ma odmienną doktrynę, są bezzasadne” (Znaniecki, 1984, s. 118).

$\mathrm{Z}$ kolei w historyczno-socjologicznym aspekcie analizy dyskursu politologicznego uwaga koncentruje się na roli organizacji i instytucji badawczych, których podstawową funkcją - według Williama McKinleya - jest narzucanie subiektywnych oglądów rzeczywistości na jej obiektywną recepcję (McKinley, 2003, s. 143). W ramach tej funkcji dokonywane jest sankcjonowanie charakterystycznego dla danej tradycji porządku wypowiedzi i metodologicznej dyscypliny badań $w$ realizowanych programach badawczych ${ }^{7}$. Tu z kolei natura dyskursu okazuje się bliższa wizji Michela Foucaulta (2002, s. 7-8; zob. też Komendant, 1996). Tradycje, wyznaczając określone podejścia badawcze, stanowią wzorce organizacji badań, których wartość ocenia się na podstawie metodologicznej poprawności. W tym kontekście komunikacja w większym stopniu opiera się na wypowiedziach autorytatywnych, arbitralnych i opiniotwórczych. Istotna jest tu zwłaszcza rola tych organizacji badawczych, które w zakresie kompetencyjnym mają instytucjonalne formy wpływu, pozwalające autorytatywnie orzekać o prawomocności wysiłków poznawczych. Mogą one także sankcjonować swoje orzeczenia, wykluczając określone formy badań jako niewłaściwe, nieuprawnione czy niezgodne $\mathrm{z}$ formalnymi wzorcami uprawiania nauki. Być może zależności te wyrażają się w procedurach przewodów prac promocyjnych, w trakcie których dokonywana jest choćby krytyka źródeł naukowych i następuje weryfikacja odwołań w przypisach do autorytatywnych i opiniotwórczych

Formy wypowiedzi uznawanych za „naukowe” podlegają nie tylko zasadom racjonalności, ale także formalnej standaryzacji. Może to dotyczyć np. form przypisów czy stylistyki wypowiedzi charakterystycznych dla prac naukowych (Westwood, Clegg, 2003, s. 15). 
pozycji wydawniczych, co jest jednym z kryteriów szacowania wartości pracy badawczej8.

Badacze dyskursu sporo uwagi zwracają na jego kulturowe uwarunkowania. Można je postrzegać przez pryzmat wpływów związanych z jednej strony z czynnikami endogennymi i ewolucją samej kultury następującej w wyniku modernizacji społecznej, z drugiej zaś z czynnikami zewnętrznymi i zjawiskiem interferencji kręgów kulturowych czy wręcz cywilizacyjnych. W tym pierwszym kontekście treść dyskursu badawczego jest odzwierciedleniem znaczących konfliktów, kryzysów czy innych zjawisk przyczyniających się do przełomów społeczno-kulturowych w danym społeczeństwie. Dynamizują one debaty naukowe, kształtując przy tym naturę i formy dyskursu oraz zmiany w sposobie postrzegania i myślenia o społecznej rzeczywistości (Alexander, Smelser, 1999, s. 3-4). W konsekwencji wobec odmiennej dla poszczególnych kręgów specyfiki kulturowej tradycje badawcze rozwijane są z zastosowaniem charakterystycznych dla danego kraju i języka pojęć czy terminów (Alexander, 1995, s. 542-544). W ten sposób dane podejścia badawcze wzbogacają się o typowe dla danej kultury historyczne konotacje bądź wzory interpretacyjne.

Prawidłowości te uwzględnia się także $\mathrm{w}$ badaniach poświęconych uwarunkowaniom rozwoju teorii politycznej. W procesach badawczych wykorzystuje się bowiem nie tylko sformalizowane narzędzia, umożliwiające uzyskanie względnie precyzyjnych pomiarów i zobiektywizowanych wyników. Równie istotne w procesie konceptualizacji, formułowania problemów i ich interpretacji jest społeczne rozumienie rzeczywistości, które w części opiera się na kulturowo wyznaczonych determinantach. Są one m.in. rezultatem zawartych w mowie czy piśmie kontekstów, a także wyznaczanych w trakcie zróżnicowanych środowiskowo praktyk idiomów i symboli (Vout, 1995, s. 99-100). Znaczenie tych czynników podkreśla m.in. Klaus von Beyme, dostrzegając, iż na kształt teorii politycznych istotny wpływ wywierają tradycje naukowe i style myślenia właściwe poszczególnym krajom i przyjętym w nich formom organizacji systemu nauki, które w długofalowej perspektywie wyznaczają określone preferencje teoretyczne i trendy rozwojowe (von Beyme, 2007, s. 307).

Z pewnością nie można bagatelizować ich roli w uprawomocnieniu refleksji, stanowisk, a nawet całych szkół teoretycznych. Charakterystycznym przykładem takiej kulturowej delegitymizacji były próby negowania dorobku polskiej politologii rozwijanej w okresie PRL. Sam fakt takiej proweniencji, nawet w środowisku poważanych - choć politycznie zaangażowanych - badaczy, mógł stanowić zasadniczy argument dezawuujący teoretyczne stanowisko formułowane w kategoriach materializmu dialektycznego (Tarkowski, 1994, s. 13-15).

Więcej o funkcjach tradycji i autorytetów w ocenie prac badawczych zob. Westwood, Clegg, 2003, s. 15. 
Oczywiście w tych uwarunkowaniach można zaobserwować także zachodzenie odwrotnych zależności. Ilustruje ja wyraźnie praktyka ideologicznego nadzoru nad teoretyczną i metodologiczną podstawą prowadzonych badań w byłych państwach demokracji socjalistycznych. Ówczesna władza, kontrolując zarówno materialne, jak i symboliczne zasoby organizacji nauki, sprzyjała preferowaniu dialektycznego i historycznego materializmu jako naukowo uprawomocnionych podstaw badań, deprecjonując nierzadko stanowiska $\mathrm{z}$ nimi sprzeczne. Choć w Polsce nadzór ten nie był tak silny jak w krajach byłego Związku Radzieckiego, uznawany jest za istotny czynnik warunkujący możliwości rozwoju nowoczesnej politologii i kształtujący strukturę badań politologicznych (Klingemann, 2002, s. 206-212)9. Niemniej, jak podkreśla Tadeusz Klementewicz, w rzeczywistości uwarunkowania badań politologicznych tego okresu są bardziej złożone, a znaczącą rolę odgrywała tu m.in. praktyka zastępowania sfery metodologicznej świadomością potoczną. W tym sensie część badań miała charakter "ateoretyczny”, oparty na potocznej wizji świata i wynikającej z niej interpretacji polityki, rodzajowo odmiennej od implikacji pojęciowych, jakie niosła teoria marksistowska (Klementewicz, 1991, s. 31).

Kwestie kulturowych uwarunkowań dyskursu, nieuchronnie odnoszą się do pojęcia języka jako podstawowego czynnika umożliwiającego przekaz komunikacyjny. Między innymi z tego względu w praktyce akademickiej dyskurs naukowy ma charakter zdecentralizowany i kulturowo sfragmentaryzowany. Pomijając kraje kultury wschodniej, można jednak zauważyć, że „mainstream” dyskursu politologicznego odbywa się w języku angielskim. W tym kontekście zarówno zasoby organizacyjne, jak i uwarunkowania kulturowe powodują, iż współczesny globalny dyskurs politologiczny zdominowany jest przez przedstawicieli krajów anglojęzycznych, a w ilościowym wymiarze przez kontynent Ameryki Północnej. Symptomatyczne są tu dane przytaczane przez Evrona Kirkpatricka, jeszcze w latach 70. XX w. dyrektora wykonawczego APSA (Amerykańskiego Stowarzyszenia Nauk Politycznych): „Na siedemnaście tysięcy pracujących obecnie politologów, czternaście tysięcy żyje i pracuje w Stanach Zjednoczonych. Bez względu na liczbę politologicznych publikacji 95 procent wydawanych jest także w Stanach" (Freeman, 1991, s. 15 i n.) ${ }^{10}$.

Autor klasyfikuje kraje realnego socjalizmu do trzech grup: kraje z wysokim stopniem ideologicznej kontroli: Estonia, Łotwa i Litwa, Czechosłowacja, Bułgaria i Rumunia; kraje z umiarkowanym stopniem ideologicznej kontroli: Węgry i Polska; kraje z niskim stopniem ideologicznej kontroli: Słowenia.

10 Ilościowa przewaga politologii amerykańskiej nie jest jednak tożsama z jakościową dominacją i wpływem na teorię polityczną. Można w tym względzie zgodzić się z Klausem von Beymem, który zauważa, iż z reguły w ocenach stanu teorii politycznej udział Europejczyków jest często pomijany bądź przynajmniej niedoceniany. Wedle autora w amerykańskiej politologii 
Wpływy i oddziaływanie na orientacje badawcze głównych nurtów teoretycznych można więc również postrzegać jako konsekwencję łatwiejszego dostępu do kanałów dystrybucji wiedzy, które poprzez zaangażowanie środków ekonomicznych, uznawane są za bardziej prestiżowe i opiniotwórcze. W trakcie organizacji badań wykorzystywane są przede wszystkim zasoby, które mają znaczenie w procesie konstruowania, autoryzacji i uprawomocnienia podejść badawczych, będących wynikiem dyskusji, negocjacji i uzgadniania stanowiska ${ }^{11}$. Dotyczą one edytorskiej kontroli wydawnictw czy placówek badawczych nad najbardziej prestiżowymi i wpływowymi czasopismami, a także możliwości ich finansowania, reklamy i zabiegów marketingowych popularyzujących określone dokonania naukowe. Zasoby, którymi dysponują te molochy wydawnicze, i środki, jakie przeznaczają na promocję swoich publikacji, niezależnie od wartości poznawczej prezentowanych w nich podejść niewątpliwie znacząco przyczyniają się do zasięgu ich oddziaływania. Najważniejsze podejścia czy szkoły teoretyczne prezentują swój dorobek w publikacjach wydawanych przez wielkie wydawnictwa o zasięgu globalnym, których struktura własnościowa zazwyczaj odzwierciedla dominację amerykańskich przedsiębiorstw (więcej na ten temat zob. Colomy, Brown, 1992, s. 70-81). Na znaczenie tych kwestii zwracał uwagę m.in. Gabriel Almond, charakteryzując sukces tzw. szkoły chicagowskiej, która dzięki menadżerskim zdolnościom Charlesa Merriama, zdołała przyciągnąć i efektywnie wykorzystać kapitał sponsorów (zob. Almond, 1990, s. 313-314; Almond, 2007, s. 64-66).

W świetle tych konstatacji trzeba zauważyć, iż organizacyjno-ekonomiczne i kulturowe uwarunkowania dyskursu naukowego stawiają w trudnej sytuacji badaczy krajów niewładających językiem angielskim, w tym także polskojęzycznej politologii. Ograniczenia we władaniu językiem jako podstawowym medium komunikacji redukują wpływy innych niż anglojęzyczne dyskursów politologicznych na rozwój głównych tradycji badawczych. Mogą one ewentualnie rozwijać bądź aplikować peryferyjne otoczenie rdzenia poszczególnych tradycji teoretycznych, mając niewielkie szanse na znaczący głos w globalnym dyskursie bez anglojęzycznych przekładów. Znamienne w tym względzie są uwagi Jerzego Łozińskiego, tłumacza niemieckojęzycznych pozycji z zakresu politologii. Uzasadniając preferowanie przekładu na język polski książki niemieckiego politologa Klausa von Beyme, dostrzega znaczący fakt kulturowy:

stosunkowo wysoką pozycję zajmuje jedynie dorobek Jürgena Habermasa i francuskich postmodernistów (von Beyme, 2007, s. 24).

11 Charakter tak rozumianego dyskursu naukowego oraz znaczenie prowadzonych w jego ramach negocjacji i kompromisu były w latach 90. przedmiotem realizacji programu badawczego, którego opublikowane wyniki uwydatniają m.in. rolę i sposoby wykorzystania takich zasobów. Chodzi tu o prace prezentujące wyniki badań empirycznych nad dyskursem naukowym, takich autorów jak: Collins, 1985; Pinch, 1986; McKenzie, 1990. 
Oto najpierw amerykańskie nauki społeczne pełnymi garściami czerpią z dokonań (także terminologicznych) niemieckich - rozumiejących - nauk społecznych, a po upływie mniej więcej trzech ćwierci wieku widzimy, jak niemiecka politologia ulegle przejmuje gotowe frazy angielskie, a nawet składnię języka politologii amerykańskiej. [...] Jak widać, stały się one terminami technicznymi także w innych kręgach językowych (Łoziński, 2007, s. 11).

W kontekście zasygnalizowanych tu jedynie językowych uwarunkowań dyskursu można założyć, iż proces naukowego uprawomocnienia stanowisk teoretycznych rozwijanych w krajach anglosaskich w dużej mierze zależy też od otwartości badaczy na filozoficzne idee i nowe ruchy teoretyczne, których asocjacja w kontekście anglojęzycznej dominacji globalnego dyskursu politologicznego jest łatwiejsza i bardziej dostępna badaczom władających tym językiem. Dużą rolę w zakresie popularyzacji i włączaniu do naukowego dyskursu nowych treści odgrywają międzynarodowe organizacje zrzeszające badaczy polityki. Tworzą one struktury sposobne dla komunikacji w kształtowaniu i uprawomocnianiu podejść teoretycznych w ramach dyskursu akademickiego ${ }^{12}$. Obecnie w czasach masowej komunikacji i tendencji do globalizacji dyskursu, niewątpliwie wzrasta znaczenie takich międzynarodowych organizacji badawczych w ustalaniu statusu głównych stanowisk badawczych, tradycji teoretycznych, a także metod wykorzystywanych w nauce o polityce, które są w coraz większym stopniu kształtowane i standaryzowane w międzynarodowym dyskursie akademickim. Również na tym poziomie najważniejszą rolę odgrywają organizacje międzynarodowe, które formalizują dyskurs, nadając mu instytucjonalną rangę. Richard Merritt i Elisabeth Hanson, analizując funkcje międzynarodowego kongresu politologicznego IPSA, podkreślają, iż to właśnie w tego typu spotkaniach uczestnicy poszukują możliwości porozumienia w bardziej sformalizowanych kanałach komunikacji. W tym wyraża się kluczowa funkcja organizacji międzynarodowych kongresów naukowych (Merritt, Hanson, 1989, s. 122). Autorzy opracowania zwracają też uwagę, iż takie kongresy formalizują i utrwalają nieformalną hierarchię wśród badaczy. Uczestnicy kongresu są postrzegani

12 Do najważniejszych organizacji międzynarodowych zrzeszających badaczy polityki zalicza się z reguły: International Political Science Association (IPSA), Central European Political Science Association (CEPSA), The European Consortium for Political Research (ECPR). Przy czym wszystkie te organizacje międzynarodowe dążą do tworzenia narodowych oddziałów. Przykładem może być Międzynarodowe Towarzystwo Nauki o Polityce (IPSA) i jego narodowe oddziały (w Polsce PTNP), w ramach których powoływane bywają specjalne organy mające koncentrować się na pracach nad określoną problematyką, np. uformowany w latach 70. w ramach IPSA specjalny Komitet do spraw konceptualizacji i analizy terminologicznej COCTA (Committee on Conceptual and Terminological Analysis). 
jako elita wiedzy danej dyscypliny, a partycypacja w takim spotkaniu wiąże się z przyznaniem wyższego statusu indywidualnym badaczom i umożliwia dostęp do międzynarodowej dyscyplinarnej elity.

Dla politologa analiza dyskursu wraz z całokształtem kulturowych, a zwłaszcza organizacyjnych i instytucjonalnych uwarunkowań powinna być szczególnie bliska obszarowi jego zainteresowań. Bowiem to właśnie te aspekty pozwalają na uchwycenie wyraźnych cech obecności władzy, wpływu, kontroli bądź sankcji, czyli atrybutów i integralnych komponentów polityki. Z tego względu, jak podkreślają Robert Westwood i Stewart Clegg, dyskursywny charakter organizacji badań jest ściśle związany z politycznością nauki (Westwood, Clegg, 2003, s. $1-19)^{13}$. Postrzeganie nauki jako historycznie i kulturowo uwarunkowanej praktyki społecznej, opartej na procesie rywalizacji posiada wyraziste aspekty politycznej walki o władzę, w której kontrola dyskursu jest zasobem umożliwiającym dominację. Cechy polityczności można także dostrzec w samym zjawisku rywalizacji tradycji badawczych, które niezależnie od specyfiki debaty akademickiej jest formą hierarchicznej strukturyzacji wpływu opartej na wypracowanym autorytecie. Podkreśla to w swojej definicji Charles E. Lindblum, twierdząc, że "polityka to walka o autorytet, wśród rywalizujących na scenie politycznej aktorów" (Dahl, Stinebrickner, 2007, s. 72).

Jej najistotniejszym aspektem jest również kontrola, która przez standardy i dyscyplinę jest integralnie wpisana w organizację wiedzy. Ilustruje to choćby przytaczany przez M. Foucaulta przykład sytuacji egzaminacyjnej, gdzie egzaminujący arbitralnie dyscyplinuje poprawność sądów egzaminowanego (Foucault, 1993, s. 212-241). Jednocześnie przykład ten wyraziście pokazuje funkcjonalną wykładnię zjawiska władzy ujmowanej jako „uogólniona zdolność, zapewniająca wykonywanie przez jednostki nałożonych przez nie w systemie zbiorowego działania zobowiązań, które są legitymizowane przez dążenie do wspólnych celów" (Parsons, 1969, s. 357). W ten sposób nauka o polityce, formułując klasyfikacje, twierdzenia, wzorce procedur badawczych i modele analizy uznane $\mathrm{w}$ dyskursie akademickim za uprawomocnione, dokonuje swoistej dystrybucji legitymizowanej recepcji świata i polityki ${ }^{14}$. Zależność tę czytelnie przedstawia Ted. C. Lewellen, argumentując: „Wiedza nie może być separowana od władzy i odwrotnie. Roszczenia badaczy, aby podporządkować rozwój społeczny czy działania polityczne wiedzy i rozumowi, są w istocie żądaniami władzy" (Lewellen, 2003, s. 191-192).

13 W szerszym ujęciu dyskurs akademicki można rozpatrywać na trzech poziomach - polityki, programów badawczych i filozofii (zob. Schmidt, 2008, s. 303-326).

14 Jest to swoiste rządzenie przez dyskusję (zob. Majone, 1999, s. 377-382). 


\section{Literatura}

Alexander, J.C. (1995). "How 'National' Is Social Theory”. Schweizerische Zeitschrift für Soziologie, vol. 21 (3).

Alexander, J.C., Smelser, N.J. (1999). “The Ideological Discourse of Cultural Discontent: Paradoxes, Realities and Alternative Ways of Thinking”. In: N.J. Smelser, J.C. Alexander (eds.). Diversity and Its Discontents. Cultural Conflict and Common Ground in Contemporary American Society. Princeton: Princeton University Press.

Almond, G.A. (1990). “Appendix B: Chicago Days”. In: G.A. Almond, A Discipline Divided: Schools and Sects in Political Science. Newbury Park-London-New Delhi: SAGE Publications.

Almond, G.A. (2007). "Structural Functionalism and Political Development". In: G.L. Munck, R. Snyder (eds.). Passion, Craft and Method in Comparative Politics. Baltimore: The Johns Hopkins University Press.

Babbie, E. (2004). Badania społeczne w praktyce, przeł. W. Betkiewicz [i in.]. Warszawa: Wydawnictwo Naukowe PWN.

Beyme, K. von (2007). Współczesne teorie polityczne, przeł. J. Łoziński. Warszawa: Wydawnictwo Naukowe "Scholar”.

Collins, H.M. (1985). Changing Order: Replication and Induction in Scientific Practice. Beverly Hills: Sage.

Colomy, P., Brown, J.D. (1992). "Elaboration, Revision, Polemic and Progress in the Second Chicago School”. In: G.A. Fine (ed.). The Second Chicago School of Sociology. Chicago: University of Chicago Press.

Crossley, K. (2005). Key Concepts in Critical Social Theory. Thousand Oaks: Sage.

Dahl, R.A., Stinebrickner, B. (2007). Współczesna analiza polityczna, przeł. P.M. Kazimierczak. Warszawa: Wydawnictwo Naukowe Scholar.

Dant, T. (1991). Knowledge, Ideology and Discourse: A Sociological Perspective. New York: Routledge.

Foucault, M. (1993). Nadzorować i karać: narodziny więzienia, przeł. T. Komendant. Warszawa: Aletheia.

Foucault, M. (2002). Porządek dyskursu: wykład inauguracyjny wygłoszony w Collège de France 2 grudnia 1970 roku, przeł. M. Kozłowski. Gdańsk: Słowo/Obraz Terytoria.

Freeman, D.M. (1991). “The Making of a Discipline”. In: W.J. Crotty (ed.). Political Science: Looking to the Future. Evanston, IL: Northwestern University Press.

Gajda, S. (1999). „Współczesny polski dyskurs naukowy”. W: S. Gajda (red.). Dyskurs naukowy - tradycja i zmiana. Opole: Wydawnictwo Uniwersytetu Opolskiego.

Habermas, J. (2005). Teoria działania komunikacyjnego. Racjonalność działania a racjonalność społeczna, przeł. A.M. Kaniowski, t. 1. Warszawa: Wydawnictwo Naukowe PWN.

Kamiński, S. (1981). Nauka i metoda. Pojęcie nauki i klasyfikacja nauk. Lublin: Towarzystwo Naukowe KUL. 
Klementewicz, T. (1991). Spór o model metodologiczny nauki o polityce. Warszawa: Instytut Studiów Politycznych Polskiej Akademii Nauk.

Klingemann, H.D. (2002). "Political Science in Central and Eastern Europe: National Development and International Integration”. In: M. Kaase, V. Sparschuh (eds.). Three Social Science Disciplines in Central and Eastern Europe: Handbook on Economics, Political Science and Sociology (1989-2001). Berlin-Bonn-Budapest: Lit Verlag.

Komendant, T. (1996). Władze dyskursu. Michel Foucault w poszukiwaniu siebie. Warszawa: Wydawnictwo Spacja.

Krauz-Mozer, B. (2007). Teorie polityki. Założenia metodologiczne. Warszawa: Wydawnictwo Naukowe PWN.

Lewellen, T.C. (2003). Political Anthropology: An Introduction. Westport: Praeger.

Łoziński, J. (2007). „Uwaga od tłumacza”. W: K. von Beyme, Współczesne teorie polityczne, przeł. J. Łoziński. Warszawa: Wydawnictwo Naukowe „Scholar”.

Majone, G. (1999). "Policy Analysis and Public Deliberation”. In: T. Miyakawa (ed.). The Science of Public Policy: Essential Readings in Policy Sciences, vol. 2. New York: Routledge.

Mansfield, E.D., Sisson, R. (red.) (2003). The Evolution of Political Knowledge: Theory and Inquiry in American Politics. Columbus, OH: Ohio State University Press.

McKenzie, D. (1990). Inventing Accuracy. Cambridge: MIT Press.

McKinley, W. (2003). "From Subjectivity to Objectivity: A Constructivist Account of Objectivity in Organization Theory”. In: R.I. Westwood, S. Clegg (eds.). Debating Organization. Point - Counterpoint in Organization Studies. Malden: Blackwell Publishing.

Merritt, R.L., Hanson, E.C. (1989). Science, Politics and International Conference. A Functional Analysis of the Moscow Political Science Congress. London: Boulder.

Nelson, J.S. (1998). Tropes of Politics: Science Theory, Rhetoric, Action. Madison, WI: University of Wisconsin Press.

Novotny, H. (1991). "Knowledge for Certainly: Poverty, Welfare Institutions and Institutionalization of Social Science”. In: P. Wagner, B. Wittrock, R. Whitley (eds.). Discourses on Society. The Shaping of the Social Science Disciplines. Boston: Kluwer Academic Publisher.

Parsons, T. (1969). Politics and Social Structure. New York: Free Press.

Pinch, T. (1986). Confronting Nature: The Sociology of Neutrino Detection. Dordrecht: Reidel.

Ritzer, G., Goodman, D.J. (2004). Modern Sociological Theory. New York: McGraw-Hill. Schmidt, V.A. (2008). "Discursive Institutionalism: The Explanatory Power of Ideas and Discourse”. Annual Review of Political Science, vol. 11 (June).

Strydom, P. (2000). Discourse and Knowledge: The Making of Enlightenment Sociology. Liverpool: Liverpool University Press. 
Tarkowski, J. (1994). Władza i społeczeństwo w systemie autorytarnym. WarszawaToruń: Wydawnictwo Adam Marszałek.

Thompson, J. (1998). Discourse and Knowledge: Defense of the Collectivist Ethics. London: Routledge.

Turner, J.H. (2004). Struktura teorii socjologicznej, przeł. G. Woroniecka [i in.]. Warszawa: Wydawnictwo Naukowe PWN.

Vout, M. (1995). "Studying Developments of the Discipline: Philosophy of Method for the History of Social Sciences”. In: D. Easton, J.G. Gunnell, M.B. Stein (eds.). Regime and Discipline: Democracy and the Development of Political Science. Ann Arbor: University of Michigan Press.

Westwood, R., Clegg, S. (2003). “The Discourse of Organization Studies: Dissensus, Politics and Paradigms". In: R. Westwood, S. Clegg (eds.). Debating Organization. Point-Counterpoint in Organization Studies. Oxford: Blackwell Publishing.

Znaniecki, F. (1984). Społeczne role uczonych, przeł. J. Szacki. Warszawa: PWN.

\section{Streszczenie}

Artykuł porusza problematykę naukowego uprawomocnienia refleksji teoretycznej w warunkach dyskursu akademickiego. Zasadnicza teza zakłada, że status stanowiska, szkoły czy tradycji teoretycznej jest uwarunkowany z jednej strony merytoryczną argumentacją odwołującą się do racjonalnego uzasadniania i eksplanacyjnego pragmatyzmu, z drugiej zaś przez wiele czynników pozaracjonalnych, które determinują współczesny dyskurs w środowisku naukowym. Autor zwraca tu uwagę zarówno na kulturowe, jak i organizacyjne oraz instytucjonalne uwarunkowania dyskursu.

Słowa kluczowe: teoria polityki, teoria polityczna, dyskurs akademicki, naukowe uprawomocnienie wiedzy, refleksja teoretyczna 